\title{
Article \\ Hot Resistance of Spores from the Thermophilic Bacillus horneckiae SBP3 of Shallow Hydrothermal Vent Origin Elucidated by Spectroscopic Analyses
}

\author{
Vincenzo Zammuto ${ }^{1} \mathbb{D}$, Maria Teresa Caccamo ${ }^{2, *} \mathbb{C}$, Salvatore Magazù ${ }^{2}$, Antonio Spanò ${ }^{1}$, Salvatore Guglielmino ${ }^{1}$ \\ and Concetta Gugliandolo ${ }^{1}$ (1) \\ 1 Department of Chemical, Biological, Pharmaceutical and Environmental Sciences, Messina University, \\ Viale Ferdinando Stagno D’Alcontres 31, 98166 Messina, Italy; vzammuto@unime.it (V.Z.); \\ aspan@unime.it (A.S.); sguglielm@unime.it (S.G.); cgugliandolo@unime.it (C.G.) \\ 2 Department of Mathematics and Computer Science, Physics and Earth Science, Messina University, \\ Viale Ferdinando Stagno D'Alcontres 31, 98166 Messina, Italy; smagazu@unime.it \\ * Correspondence: mcaccamo@unime.it
}

check for updates

Citation: Zammuto, V.; Caccamo, M.T.; Magazù, S.; Spanò, A.; Guglielmino, S.; Gugliandolo, C. Hot Resistance of Spores from the

Thermophilic Bacillus horneckiae SBP3 of Shallow Hydrothermal Vent Origin Elucidated by Spectroscopic Analyses. Appl. Sci. 2021, 11, 4256. https:// doi.org/10.3390/app11094256

Academic Editor: Takeo Minamikawa

Received: 1 April 2021

Accepted: 6 May 2021

Published: 8 May 2021

Publisher's Note: MDPI stays neutral with regard to jurisdictional claims in published maps and institutional affiliations.

Copyright: (c) 2021 by the authors. Licensee MDPI, Basel, Switzerland. This article is an open access article distributed under the terms and conditions of the Creative Commons Attribution (CC BY) license (https:// creativecommons.org/licenses/by/ $4.0 /)$.

\begin{abstract}
Spores from Bacillus horneckiae SBP3 (SBP3) of shallow hydrothermal vent origin have recently been reported to survive extreme conditions more often than their close phylogenetic relatives B. horneckiae DSM $23495^{\mathrm{T}}$ (BHO) and B. subtilis 168 (BSU) used in biodosimetry and the space microbiology model. To investigate the structures of unheated spores, Fourier-transform infrared spectroscopy (FTIR) analysis was used. The FTIR spectra of the spores from the strains SBP3, $\mathrm{BHO}$ and BSU mainly differed in the region that referred to lipids and amino acids or polypeptides, indicating that the SBP3 spores were richer in saturated fatty acids, and the protein structures of SBP3 and BHO spores were more aggregated and complex than those of BSU. SBP3 spores were more resistant $\left(\mathrm{LD}_{90}=4.2 \pm 0.3 \mathrm{~min}\right)$ to wet heat treatment $\left(98^{\circ} \mathrm{C}\right)$ than $\mathrm{BHO}\left(\mathrm{LD}_{90}=1.8 \pm 0.2 \mathrm{~min}\right)$ and $\mathrm{BSU}\left(\mathrm{LD}_{90}=2.9 \pm 0.5 \mathrm{~min}\right)$ spores were. In comparison to the untreated spores, the Raman spectra of the wet-heat-treated SBP3 spores showed minor variations in the bands that referred to proteins, whereas major changes were observed in the bands that referred to lipids and amide I in the heated BSU spores and to both lipids and proteins bands in the treated BHO spores. These results suggest that the major stability of SBP3 spore proteins could explain their greater resistance to wet heat compared to $\mathrm{BHO}$ and BSU. Our findings provide basic information for further comparative studies into spore responses to natural and laboratory stresses, which are useful in several different fields, such as astrobiology.
\end{abstract}

Keywords: Bacillus spores; Raman; FTIR; spore resistance; heat resistance; extremophiles

\section{Introduction}

Natural environments characterized by extremes in one or more physico-chemical conditions are usually inhabited by microbes, or extremophiles, possessing well-adapted mechanisms to contrast the stresses encountered in their own habitats. Extremophiles exhibiting multiple adaptative mechanisms, or poly-extremophiles, are ideal candidates for experimentally addressing questions to extend our knowledge in different disciplines, with implications for the origin and the limits of terrestrial life or astrobiological purposes, and to develop novel strategies to prevent microbial contamination [1-3].

Wet heat is used regularly for the inactivation of bacterial spores, generally at $\geq 100{ }^{\circ} \mathrm{C}$ for short to moderate periods of time. The main feature of bacilli is their ability to produce spores that characterize forms resistant to various environmental and laboratory stresses, such as chemical oxidizing agents, sterilization techniques, extreme desiccation, wet and dry heat and ultraviolet and ionizing irradiations [3-6]. However, various factors are responsible for the increased resistance of Bacillus species spores to wet heat, including 
the following: (i) the water content of the spore core and the level and type of the spore's core mineral ions; (ii) the high level of dipicolinic acid (DPA) in the spore core; (iii) the intrinsic stability of total spore proteins and the saturation of spore DNA with $\alpha / \beta$-type small, acid-soluble spore proteins (SASPs) [4,6].

The shallow hydrothermal vents on the Eolian Islands (Italy), characterized by extreme environmental conditions such as high temperatures, low $\mathrm{pH}$, high concentrations of $\mathrm{H}_{2} \mathrm{~S}$ and hydrocarbons, etc., are clearly accessible sampling locations to investigate microorganisms inhabiting extreme marine ecosystems in order to gain new insights into microbial diversity and to isolate novel thermophiles, defined by an optimal growth temperature in the range of $45 \div 70{ }^{\circ} \mathrm{C}$, with interesting physiological characteristics and biotechnological applications $[7,8]$.

It was reported that several thermophilic Geobacillus and Bacillus strains isolated from these environments possess a higher resistance to high temperatures than their mesophilic counterparts do [3,9]. Spores' structural adaptation to high temperatures, such as the lipid composition of membranes, proteins and DNA, could allow thermophiles to resist extreme environmental conditions, such as those of shallow hydrothermal vents [3].

We previously reported that spores from Eolian thermophiles possess high and unexplored levels of resistance to several stresses that they have never naturally encountered before, such as UV-C, X-rays, hydrogen peroxide, low-pressure plasma, dry heat, space vacuum and high-energy charge particles [3,6]. Interestingly, spores from Bacillus horneckiae SBP3 DSM 103063 (SBP3), which were isolated from a shallow hydrothermal vent on Panarea Island (Eolian Islands), showed higher levels of resistance to low-pressure argon plasma and dry and wet heat than spores from its close phylogenetic relative strain $B$. horneckiae DSM 23495 (BHO), which were isolated from spacecraft assembly facilities [10], and B. subtilis 168 (BSU), which were isolated from a biodosimetry strain and space microbiology model organism [3]. SBP3 showed the same degree of spore resistance to wet heat treatment in comparison to B. pumilus SAFR-032 and B. nealsonii, which were isolated from spacecraft assembly facilities and characterized by high levels of resistance to different decontamination efforts-either chemical or physical treatments $[3,10]$.

More recently, we reported that spores from thermophiles, including those from the SBP3 strain, were more resistant to heavy ion (helium (He) and iron ( $\mathrm{Fe})$ ) irradiations than psychrophiles were [6]. The FTIR spectra showed important modifications in the bands related to the carbohydrates, lipids and proteins of spores after the more lethal Fe irradiation, explaining the block in spore germination, whereas minor changes were observed after He radiation, mainly connected to the increasing permeability of the inner membrane and alterations of receptor complex structures.

The findings allow us to hypothesize that the adaptative mechanisms to resist the thermal stress naturally experienced in the natural environment of SBP3 spores allow them to defy multiple stressors as well. Studies of responses to different stresses have, until now, been largely centered on spores of the laboratory strain B. subtilis 168, and little is known about environmental poly-extremophilic bacilli.

In this study, we investigated the resistance of spores to wet heat from B. horneckiae SBP3 in comparison to B. horneckiae DSM $23495^{\mathrm{T}}$ and B. subtilis 168 . In order to do so, we used FTIR and Raman spectroscopy techniques, which allow for the evaluation of changes in spectral bands attributed to the main biomolecules (i.e., carbohydrates, lipids and proteins). Our findings provide basic information for further comparative studies into spore responses to natural and laboratory stresses that are employed in several contexts, such as astrobiology.

\section{Materials and Methods}

\subsection{Bacterial Strains and Spore Preparation}

Bacillus horneckiae SBP3 was isolated from a sample in June 2006 close to a shallow underwater hydrothermal vent on the island of Panarea (Eolian Islands, Italy), also known as Black Point (coordinates: $38^{\circ} 38^{\prime} 23^{\prime \prime} \mathrm{N}-5^{\circ} 06^{\prime} 28^{\prime \prime} \mathrm{E}$, depth: $23 \mathrm{~m}$ ). Temperature equal to 
$130{ }^{\circ} \mathrm{C}$, $\mathrm{pH}$ value equal to 3.0 and conductivity equal to $46.20 \mathrm{mS} / \mathrm{cm}$ are the properties of the fluid emitted from Black Point [8]. B. horneckiae DSM $23495^{\mathrm{T}}$, the closest phylogenetic relative strain to B. horneckiae SBP3, and B. subtilis 168 DMS 402, the biodosimetry strain, were purchased from the German Collection of Microorganisms (DSMZ).

In order to produce spores, the strains were plated onto Shaffer's medium (containing $0.1 \% \mathrm{KCl}, 0.012 \% \mathrm{MgCl}_{2}, 0.5 \mathrm{mM}$ of $\mathrm{CaCl}_{2}, 0.01 \mathrm{mM}$ of $\mathrm{MnCl}_{2}, 0.001 \mathrm{mM}$ of $\mathrm{FeSO}_{4}$ and $8 \mathrm{~g}$ of nutrient broth) modified by the addition of $1 \% \mathrm{NaCl}$ and $2 \%$ agar. A single colony from each strain was used to inoculate the plate medium and followed by incubation at each optimal temperature: B. horneckiae SBP3 $\left(\mathrm{T}=45^{\circ} \mathrm{C}\right)$ for two days; B. horneckiae DSM $23495^{\mathrm{T}}$ $\left(\mathrm{T}=30^{\circ} \mathrm{C}\right)$ and B. subtilis $\left(\mathrm{T}=37^{\circ} \mathrm{C}\right)$ for four days. To check for the presence of spores, each culture was observed under a phase contrast microscope (BX53, Olympus Scientific Solutions America). The spores were subsequently purified as described by Setlow et al. (2007). Briefly, the spores were washed from three to ten times with sterile distilled water to remove the vegetative cells and cell debris. The purified spores were suspended in sterile distilled water and stored at $4{ }^{\circ} \mathrm{C}$.

In particular, scanning electron microscopy (SEM) (Sigma Zeiss, Germany) was employed to observe the spores. The suspensions of spores were placed onto a support of aluminum and dried at room temperature for $24 \mathrm{~h}$ and then coated with a layer $(18 \pm 0.2 \mathrm{~nm})$ of Au-Pd alloy using a coating device (MED 020, Ba Tec AG, Tucson, AZ, USA).

\subsection{FTIR Analysis}

The Fourier-transform infrared (FTIR) technique makes possible the characterization of a molecule's vibrational and rotational movements [11]. The spores from the studied Bacillus strains were analyzed by means of the Bruker Optics spectrometer FTIR Vertex $70 \mathrm{~V}$ accessorized with a diamond device. Each spectrum was obtained by summing 48 registered scans, with an energy resolution of $4 \mathrm{~cm}^{-1}$, in the $400-4000 \mathrm{~cm}^{-1}$ spectral range [11]. The data treatment, performed by means of OriginLab and MATLAB, included the following: (i) a correction for the baseline; (ii) a data smoothing treatment; (iii) a normalization for path length variations; (iv) a spectra second derivative evaluation to determine band center frequencies.

\subsection{Wavelet Cross-Correlation}

To extract the spectra degree of correlation, a Wavelet Cross-Correlation (XWT) approach was employed. More specifically, the Wavelet Cross-Correlation Coefficient (XWTC) was evaluated using the following equation:

$$
X W T C=\frac{\int W_{1}(a, \tau) W_{2}^{*}(a, \tau) d \tau}{\sqrt{W S_{1}(a) W S_{2}(a)}}
$$

where $W_{1}(a, \tau)$ is the spectrum Wavelet Transform (WT), $a$ is the scale parameter and $\tau$ is the shift parameter, while $W_{2}^{*}(a, \tau)$ is the second spectrum $W T$, and $W S_{1}$ and $W S_{2}$ are the first and the second wavelet spectra, respectively. When there is no correlation, the XWTC value is zero, while it is close to 1 for strongly correlated spectra [12-15]. For such analysis, MATLAB 2016a software (MathWorks, Natick, MA, USA) was employed.

\subsection{Spore Resistance to Wet Heat}

Moeller et al. [5] describe the evaluation of the level of spore resistance to wet heat. In short, spore suspensions $\left(10^{7}\right.$ spores $\left./ \mathrm{mL}\right)$ in distilled sterile water were heated at $98^{\circ} \mathrm{C}$ for $10,20,40$ and $60 \mathrm{~min}$. The spore survival was determined by plating aliquots $(100 \mu \mathrm{L})$ from serial dilutions onto Tryptone Soy Agar (TSA) plates. Plates were incubated at $45^{\circ} \mathrm{C}$ for SBP3 and $30^{\circ} \mathrm{C}$ for B. subtilis and B. horneckiae DSM 23495 for 18 to $36 \mathrm{~h}$, and then, the colony-forming units (CFU) were counted. The lethal dose $\left(\mathrm{LD}_{90}\right)$ based on the regression curve of the survival fraction and the standard deviation were calculated. 


\subsection{Spectroscopic Raman Analysis}

Raman scattering data were collected by the Bruker BRAVO spectrometer. The spectrometer's working range was $300-3200 \mathrm{~cm}^{-1}$, with a resolution of $10-12 \mathrm{~cm}^{-1}$ and a spot size of 10-15 microns at 10× lens; the laser sources were 785-1100 nm (Duo LASERTM). An acquisition time of $80 \mathrm{~s}$ per measurement was chosen. The investigated spectral range was $500-3000 \mathrm{~cm}^{-1}$ [16]. Data treatment was performed by means of MATLAB scripts. More specifically, the spectra were corrected for the background and then normalized to the total area. Then, the shift ratio of Raman bands was employed for spore classification, while an unpaired, two-sided Student's $t$-test was performed to evaluate the intensity ratio's statistical significance [17].

\subsection{Statistical Analysis}

Principal component analysis for statistical analysis on the peaks observed in the Raman spectra from untreated and treated spores was performed using $\mathrm{R}$ (version 3.2.2 for $\mathrm{Mac}$ ) and $\mathrm{R}$ studio (version 0.99.489 for Mac). The significance of the wet heat treatment was tested on the first three principal components (PCs) using the correlation parametric test [18].

\section{Results}

\subsection{The Morphological Spore Analysis}

SBP3 spores possess a sticky external layer, commonly attributed to the exosporium, that is quite similar to but more abundant and stickier than that of the related strain $B$. horneckiae DSM $23495^{\mathrm{T}}$ (Figure 1A,B). On the other hand, the micrograph confirmed the lack of the exosporium in B. subtilis spores (Figure 1C).

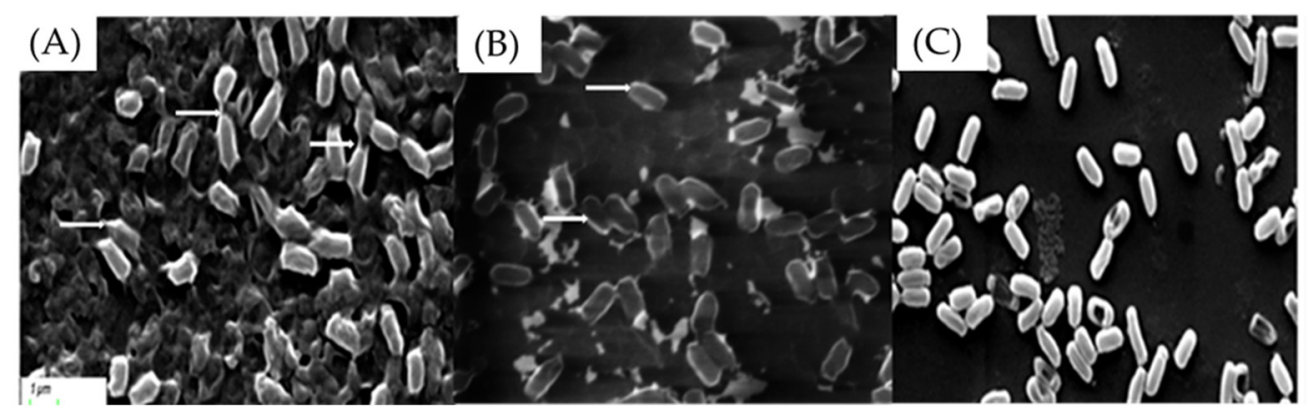

Figure 1. Scanning electron micrographs (bar: $1 \mu \mathrm{m}$ ) of spores from (A) B. horneckiae SBP3, (B) B. horneckiae DSM $23495^{\mathrm{T}}$ and (C) B. subtilis 168. Arrows indicate the exosporium layer.

\subsection{FTIR Analysis}

By means of FTIR analysis, it was possible to determine the biochemical and structural differences that were present in the investigated bacilli.

In the obtained spectra, based on the work of Vongsvivut et al. [19], the peak wavenumbers were assigned [19] (Table 1).

Figure 2 reports both the structural similarities and the differences between the regions of the spores obtained from the studied bacilli that were investigated in the FTIR spectra.

In the region referring to lipids and amide III $\left(2800-3000 \mathrm{~cm}^{-1}\right)$, peaks were present at 2854 and $2940 \mathrm{~cm}^{-1}$ for the SBP3 spore spectrum, at 2852 and $2938 \mathrm{~cm}^{-1}$ for the BHO spore spectrum and at 2850 and $2925 \mathrm{~cm}^{-1}$ for the BSU spore spectrum.

In the region of amide I, attributed to amino acids and polypeptides $\left(1560-1660 \mathrm{~cm}^{-1}\right)$, evident peaks were present at 1630 and $1620 \mathrm{~cm}^{-1}$ in the SBP3 and the BHO spectra, respectively, and at $1655 \mathrm{~cm}^{-1}$ in the BSU spectrum, suggesting different spore protein structures.

The frequency of the peaks attributable to the ring vibrations of carbohydrates (1000-1250 $\mathrm{cm}^{-1}$ ) differed from each other, suggesting that each spore possesses a unique carbohydrate structure as well as that in the nucleic acid bands $\left(900-1000 \mathrm{~cm}^{-1}\right)$. 
Table 1. FTIR band assignments for the functional groups according to Vongsvivut et al. [19].

\begin{tabular}{|c|c|c|}
\hline Wavenumber Values $\left(\mathrm{cm}^{-1}\right)$ & Band Assignment & References \\
\hline $3300-3200$ & $\begin{array}{c}\text { H-bond and } \mathrm{OH} \text { group of alcohol, phenols and } \\
\text { organic acid including nucleic acids and } \\
\text { proteins amide A }\end{array}$ & [20] \\
\hline $3100-3000$ & $\mathrm{n}(\mathrm{C}-\mathrm{H})$ of cis $\mathrm{C}=\mathrm{H}$ bonds & [21] \\
\hline$\sim 2925$ & Lipids & [21] \\
\hline $1700-1750$ & $\begin{array}{c}\text { Protein and esters of muramic acid and ester } \\
\text { fatty acid group }\end{array}$ & {$[22]$} \\
\hline $1660-1628$ & Amide I peptidic conformation & [23] \\
\hline$\sim 1548$ & Amide II peptidic conformation & {$[24]$} \\
\hline$\sim 1380$ & $\mathrm{CH}_{2}$ and $\mathrm{CH}_{3}$ bending from lipids, DPA amide III & {$[25]$} \\
\hline$\sim 1066$ & Ring vibrations of carbohydrates & {$[21]$} \\
\hline$\sim 966$ & $\mathrm{CH}$ conjugated trans, trans isomers & {$[26]$} \\
\hline$\sim 780$ & Nucleic acids, sugar-phosphate vicration & [27] \\
\hline
\end{tabular}

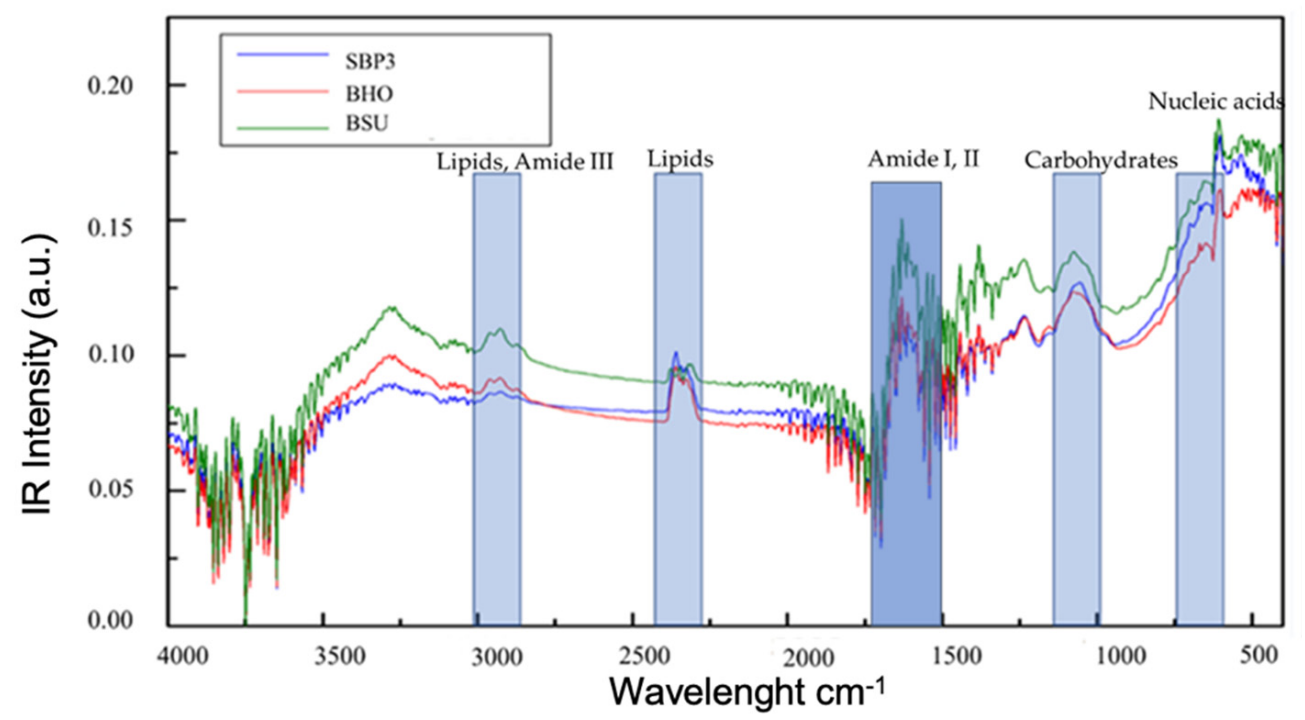

Figure 2. FTIR spectra of spores from B. horneckiae SBP3 (SBP3), B. horneckiae DSM23495 ${ }^{\mathrm{T}}$ (BHO) and B. subtilis 168 (BSU).

The FTIR analyses, coupled with the wavelet analysis of spectra from SBP3, BHO and BSU spores, are shown in Figure 3.
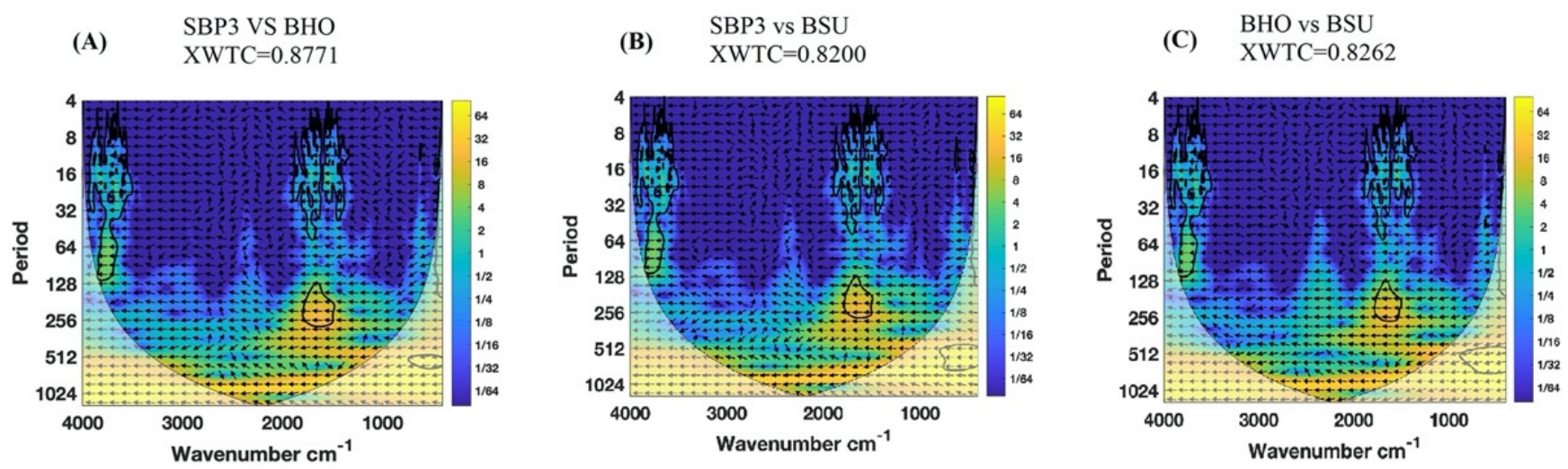

Figure 3. Comparison among FTIR spectra using the coefficient of the wavelet correlation between spores: (A) B. subtilis (BSU) 168 vs. B. horneckiae SBP3(SBP3); (B) B. horneckiae DSM 23495 ${ }^{\mathrm{T}}$ (BHO) vs. B. horneckiae SBP3; and (C) B. subtilis 168 (BSU) vs. B. horneckiae DSM $23495^{\mathrm{T}}$ (BHO). 
This analysis allowed us to distinguish each spore spectrum as a distinctive feature of each strain. The SBP3 spectrum was more similar to that of BHO $($ XWTC $=0.8771)$ (Figure 3B) than to that of BSU (XWTC $=0.8200$ ) (Figure 3A). The affinity observed between the BHO and BSU spectra was slightly higher than that between SBP3 and BSU $($ XWTC $=0.8262)($ Figure 3C).

\subsection{Resistance to Wet Heat $\left(98^{\circ} \mathrm{C}\right)$}

The survival curves of wet-heat-treated spores from the studied Bacillus spp. are reported in Figure 4. After the thermal treatment, viable spore numbers $\mathrm{N} / \mathrm{N}_{0}$, where $\mathrm{N}$ is the number of CFUs per milliliter of the treated spores and $\mathrm{N}_{0}$ represents the CFUs of the non-treated spores, decreased as the time of exposure to heat increased.
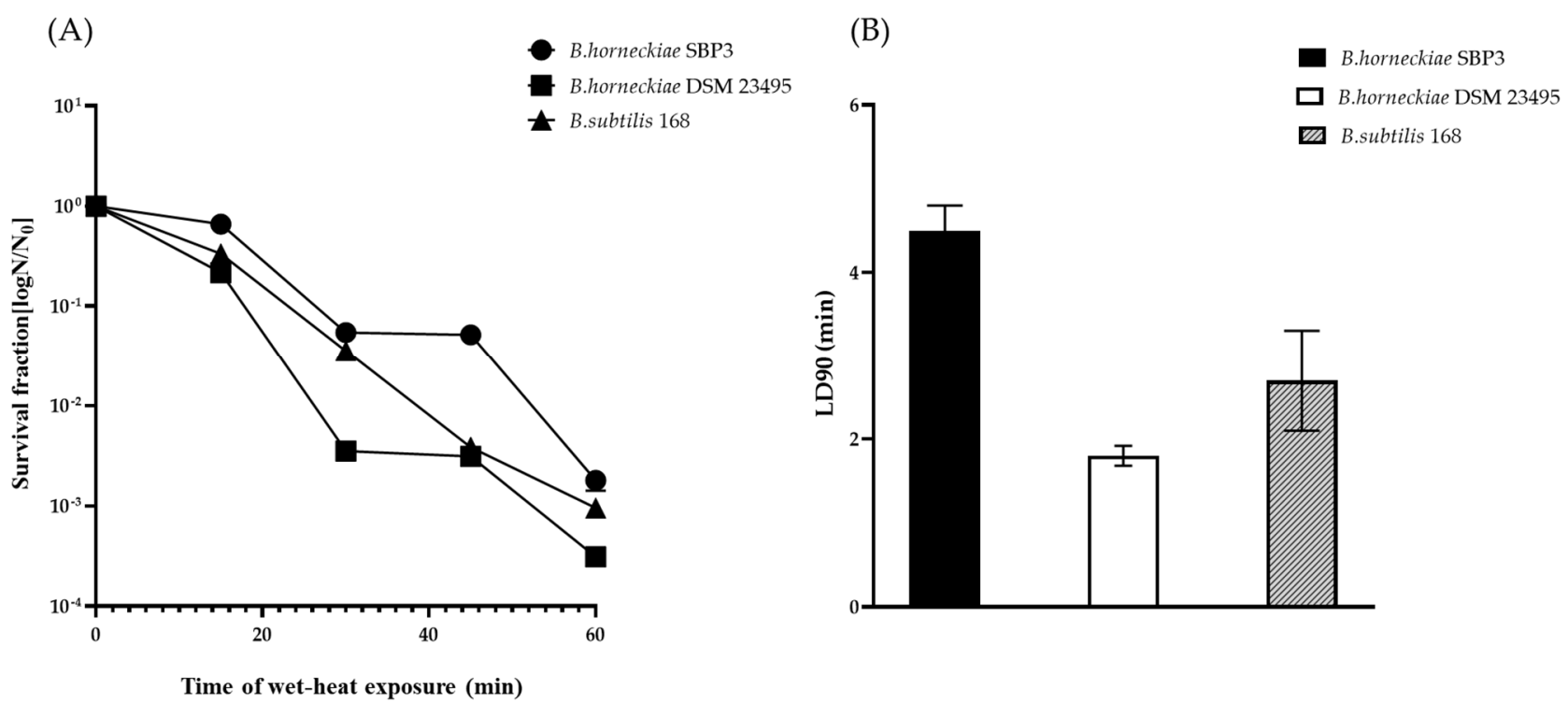

Figure 4. Resistance to wet heat $\left(98^{\circ} \mathrm{C}\right)$ of spores from B. horneckiae SBP3, B. horneckiae DSM 23495 and B. subtilis: (A) survival curves of spores and (B) bar graph displaying the $\mathrm{LD}_{90}$ values (i.e., time to reduce spore survival to $10 \%$ of the initial spore culture).

After treatment, the kinetic curves of the inactivation of the spores from SBP3 and $\mathrm{BHO}$ showed a sigmoidal shape, while those from BSU showed an exponential shape (Figure 4A). The thermophilic strain SBP3 showed the strongest spore resistance $\left(\mathrm{LD}_{90}=4.2 \pm 0.3 \mathrm{~min}\right)$ to the wet heat treatment (Figure $4 \mathrm{~B})$, followed by BSU $\left(\mathrm{LD}_{90}=2.9 \pm 0.5 \mathrm{~min}\right)$ and $\mathrm{BHO}$ spores $\left(\mathrm{LD}_{90}=1.8 \pm 0.2 \mathrm{~min}\right)$.

\subsection{Raman Spectroscopy Analyses}

The investigation of the biochemical and structural changes present in the spores from bacilli after the thermal treatment was carried out using Raman spectroscopy. Based on the work of De Gelder et al. [28], it was possible to assign the peaks (Table 2).

Table 2. Raman bands and the tentative assignment of their functional groups.

\begin{tabular}{ccc}
\hline Raman Band/Peak $\left.\mathbf{( c m}^{-\mathbf{1}}\right)$ & Tentative Assignment of Functional Group & References \\
\hline 622 & Proteins & {$[29]$} \\
661 & CaDPA & {$[30]$} \\
725 & DNA & {$[31]$} \\
780 & DNA & {$[31]$} \\
824 & CaDPA & {$[31]$} \\
864 & C-C stretch & {$[29]$} \\
1004 & Phenilanine & {$[32]$} \\
1017 & CaDPA & {$[29]$} \\
\hline
\end{tabular}


Table 2. Cont.

\begin{tabular}{ccc}
\hline Raman Band/Peak $\left.\mathbf{( c m}^{-\mathbf{1}}\right)$ & Tentative Assignment of Functional Group & References \\
\hline $1060-1070$ & Glucose-saccharide band & {$[33]$} \\
1115 & Proteins & {$[29]$} \\
$1200-1244$ & Proteins, amide III & {$[29]$} \\
1336 & DNA & {$[31]$} \\
1395 & CaDPA & {$[30]$} \\
1448 & Proteins & {$[32]$} \\
1485 & DNA & {$[31]$} \\
1555 & CaDPA & {$[31]$} \\
1582 & CaDPA & {$[31]$} \\
1624 & Proteins & {$[34]$} \\
$1645-1674$ & Proteins, amide I, lipids & {$[32]$} \\
$1700-1736$ & Lipids & {$[35]$} \\
\hline
\end{tabular}

The Raman spectra of the untreated spores and their functional groups are reported in Figure 5. As demonstrated by the FTIR analysis, the major differences among the spectra of the untreated spores were detected in the regions assigned to saccharide band/carbohydrates $\left(1060-1070 \mathrm{~cm}^{-1}\right)$, to proteins and polypeptides $\left(1645-1674 \mathrm{~cm}^{-1}\right)$ and to $\mathrm{CH}$ stretching of lipids $\left(1700-1736 \mathrm{~cm}^{-1}\right)$.

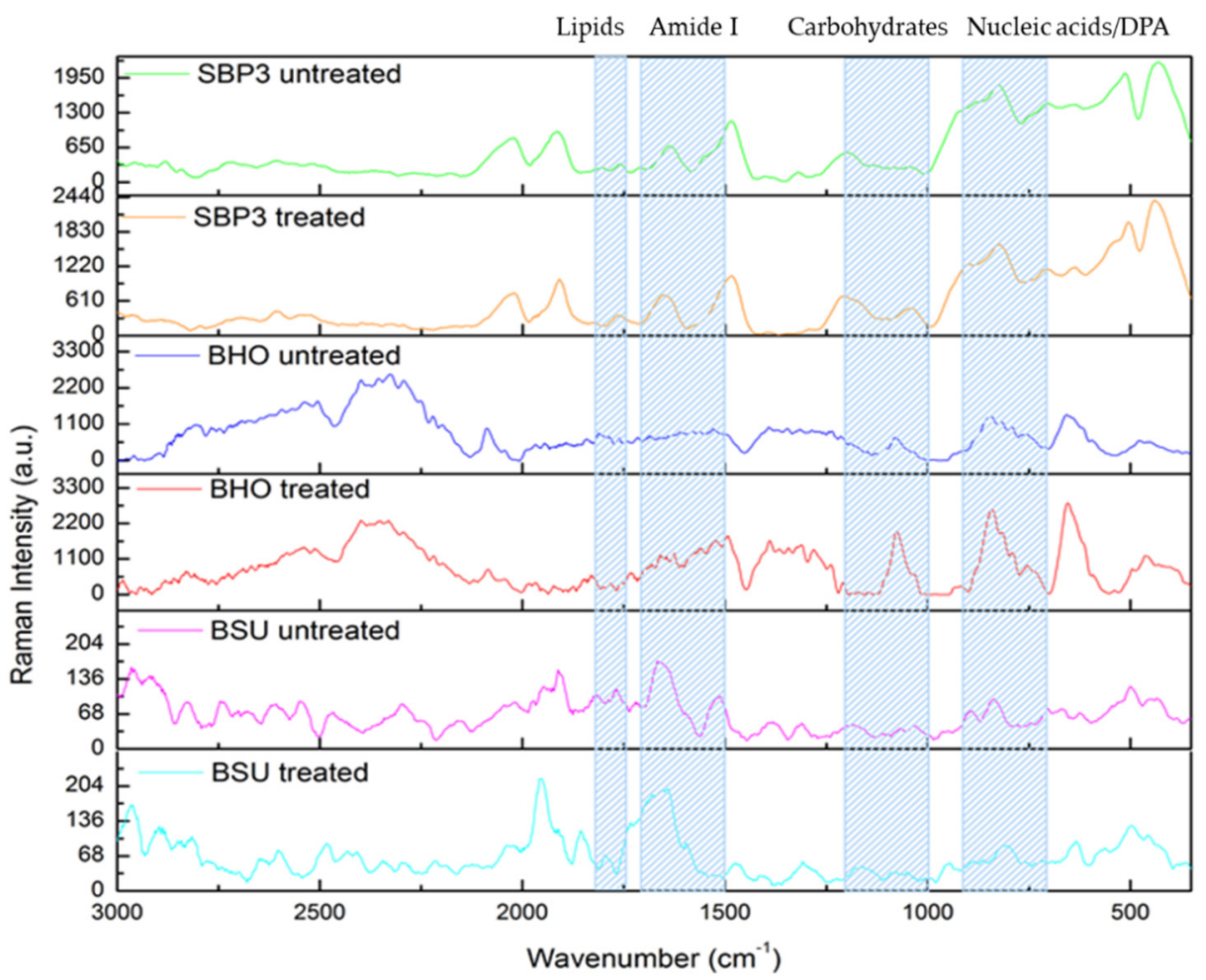

Figure 5. Raman spectra of untreated and wet-heat-treated spores from Bacillus horneckiae SBP3, Bacillus horneckiae DSM $23495 \mathrm{~T}$ (BHO) and Bacillus subtilis 168 (BSU).

After treatment, changes in the Raman spectra were observed in the region of $800-900 \mathrm{~cm}^{-1}$ attributed to DPA and nucleic acids, with the highest variation detected in BHO and the lowest in SBP3 (Figure 5). Compared to untreated spores, the spectrum of treated BHO spores showed evident peak shifts in the regions that referred to amide I $\left(1660-1674 \mathrm{~cm}^{-1}\right)$ and lipids (1700-1736 $\left.\mathrm{cm}^{-1}\right)$. Unlike untreated SBP3 spores, the spectrum of heated spores showed higher variations in the amide I region, while moderate peak variations were detected in the region attributed to lipids (Figure 5). 
To analyze the differences among the Raman spectra, a principal component analysis (PCA) was performed, and Figure 6 reports the data.

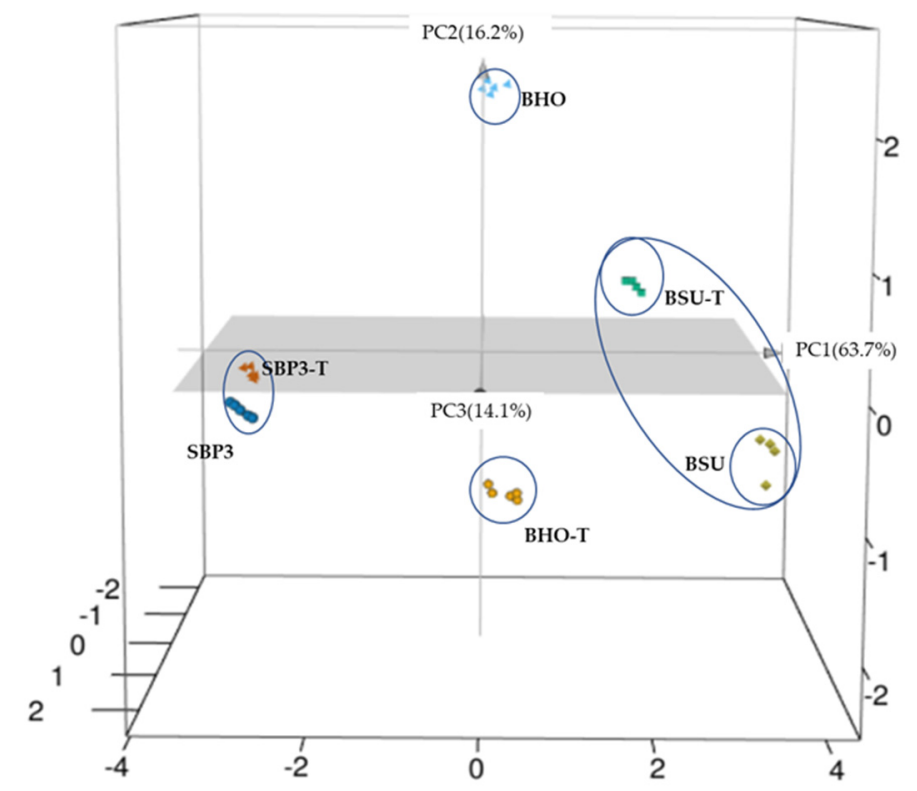

Figure 6. PCA plot of untreated and wet-heat-treated (-T) spores from Bacillus horneckiae SBP3 (SBP3), Bacillus horneckiae DSM 23495' (BHO) and Bacillus subtilis 168 (BSU).

Based on the major peaks in the Raman spectra of the spores, the PCA was performed to distinguish the spores. The three main axes explained $94.02 \%$ of the total variance. The PC1 axis, which explained $63.7 \%$ of the variance, was strongly associated with peaks related to amide I and to nucleic acids and DPA on the positive side and with nucleic acids on the negative side. The PC2 axis (16.2\% of the variance) was mainly associated with lipids on the positive side and with carbohydrates on the negative side, whereas the PC3 axis ( $14.1 \%$ of the variance) was mainly associated with amide I and carbohydrates on the positive side and lipids on the negative side.

\section{Discussion}

Spores of the thermophilic Bacillus horneckiae SBP3 possess a high degree of resistance to wet heat and survive better than those of its closest phylogenetic relative $B$. horneckiae DSM $23495^{\mathrm{T}}(\mathrm{BHO})$ and of the biodosimetry strain and astrobiological model B. subtilis 168 (BSU) [3]. The presence of spore external integuments (exosporium, cortex, coat and inner membrane) can be significant in the resistance to several stresses. The outer layer of Bacillus spores, the exosporium, consisting of glucose, lipids and proteins, constitutes the first barrier between the spore and the environment [36-39]. However, its presence differs among the different species; for example, the spores of B. horneckiae possess an exosporium, while those of $B$. subtilis do not (Figure 1), and different factors have been reported to be involved in the spore's resistance to heat [6]. Depending on what can be expected at elevated temperatures in dry conditions, spore inactivation by wet heat treatment has been previously reported not to occur through DNA damage (e.g., depurination) [40], but rather through denaturation processes that target one or more spore proteins [41,42]. Minor changes in the spore protein structure have been reported before this event, whereas major protein denaturation was detected only after the release of DPA, when the spores were already dead [4,40,42].

In this context, our study combined spectroscopy techniques with multivariate analyses to elucidate the biochemical and structural changes in the spectral bands attributed to the principal biomolecules (carbohydrates, lipids and proteins) occurring in spores of three Bacillus strains. FTIR coupled with the wavelength analysis indicated distinctive spore 
structures of the two B. horneckiae strains, confirming that this technique can help to identify spores from bacilli that also belong to the same genetic level, as reported previously [43-45]. The FTIR spectra revealed that the major differences between the untreated spores from B. horneckiae SBP3 and B. subtilis 168 were related to lipids and the secondary structures of proteins (Figure 5). According to Chou et al. [46], the peak shifts present in the amide I region of both SBP3 and $\mathrm{BHO}$ spore spectra indicated that the structural proteins were more aggregated and complex than those of BSU. Furthermore, the evident peaks observed at $1040 \mathrm{~cm}^{-1}$ in the BHO and BSU spectra suggested that their carbohydrates possess similar crystal structures but are different to those of SBP3 spores.

To overcome the intrinsic difficulties of the FTIR technique, such as the noise signals of $\mathrm{OH}$ stretching, vibrational Raman spectroscopy was used to provide the specific molecular fingerprints (i.e., the number of peaks, shifts and their shape) of spores that survived wet heat treatment, in comparison to untreated spores.

As predicted by the FTIR analysis, the PCA plot (Figure 6) presented a clear distinction among the untreated spores, with SBP3 clustered away from BSU, with the maximum distance in the PC1 axis being related to amide I and $\alpha$ - and $\beta$-pleated sheets of secondary proteins, well separated by the PC2 axis (referring to lipids). In the BSU spore spectrum, the peaks observed at 2850 and $2925 \mathrm{~cm}^{-1}$ (Figure 5), related to the $\mathrm{CH}_{2}$ stretching vibrations in the region referring to lipids, indicated the presence of a longer acyl chain and/or saturated fatty acids [26]. These data suggested that the inner membranes of BSU spores are richer in saturated fatty acids than those of SBP3 and BHO. When compared with the other two strains, the lipidic composition of the SBP3 strain (Table 3) displays the highest content of iso-C15 fatty acids (63\%) and the lowest content of anteiso-C15 (nearly 9\%) fatty acids. The fatty acid content of the SBP3 strain, specifically referring to thermophilic bacilli $[3,47]$, is highly concordant with the high temperature $\left(130^{\circ} \mathrm{C}\right)$ of the vent environment from which it was isolated.

Table 3. Percentages of the relative abundance of fatty acid methyl esters in B. horneckiae SBP3, B. horneckiae DSM $23495^{\mathrm{T}}$ and B. subtilis 168.

\begin{tabular}{|c|c|c|c|}
\hline & $\begin{array}{l}\text { Bacillus horneckiae SBP3 DSM } \\
103063 \text { Zammuto et al. [3] }\end{array}$ & $\begin{array}{c}\text { Bacillus horneckiae DSM } \\
23495^{\mathrm{T}} \text { Vayshampayan et al. [10] }\end{array}$ & $\begin{array}{c}\text { Bacillus subtilis } \\
168 \text { Roberts et al. [48] }\end{array}$ \\
\hline Temperature range $\left({ }^{\circ} \mathrm{C}\right)$ & $25-45$ & $4-40$ & $25-37$ \\
\hline \multicolumn{4}{|l|}{ Fatty acids } \\
\hline \multicolumn{4}{|l|}{ Straight chain saturated } \\
\hline C16:0 & 0.8 & 0.5 & 3.14 \\
\hline \multicolumn{4}{|l|}{ Branched saturated } \\
\hline iso-C14:0 & 3.4 & 4 & 1.13 \\
\hline iso-C15:0 & 63.1 & 54.3 & 29.27 \\
\hline iso-C16:0 & 3.5 & 2.5 & \\
\hline iso-C17:0 & 2 & 1.3 & 9.59 \\
\hline anteiso-C15:0 & 8.8 & 19.9 & 40.19 \\
\hline anteiso-C17:0 & 1.8 & 2.3 & 9.38 \\
\hline \multicolumn{4}{|l|}{ Monounsaturated } \\
\hline C16:1 $\omega 7$ c-alchol & 7.8 & 6.8 & 0.23 \\
\hline iso-C17:1 $\omega 10 \mathrm{c}$ & 3.7 & 2.3 & 1.72 \\
\hline
\end{tabular}

After the wet heat treatment, changes in the Raman spectra in the bands that referred to proteins, nucleic acids and lipids indicated different degrees of damage in spores from each strain, which could be related to their viability.

The PCA plot (Figure 6) shows the major distance between the untreated and wetheat-treated spores of both mesophilic BHO and BSU strains, indicating the occurrence of denaturation processes in their structures that could justify their lower resistance to heat compared to SBP3. Evident variations were observed in the spectral regions that referred to spore-coat structures and, particularly, to lipids of the inner membranes of $\mathrm{BHO}$ spores (Figure 5). Moreover, the spectrum of the heated spores of $\mathrm{BHO}$ showed a 
peak shift at $824 \mathrm{~cm}^{-1}$, indicating that DPA in the spore's core was released, possibly as a consequence of the extensive protein damage, as described by Coleman et al. [49] in the case of $B$. subtilis spores.

In the spectra of the treated BSU, evident peak shifts were observed in the regions associated with nucleic acids and protein structures, including SASPs [32]. These results suggest that the wet heat damage mainly involves the denaturation processes of the spore protein components rather than DNA damage, according to previously reported studies $[4,41,42]$. Therefore, the wet heat could damage spores, resulting from the release of DPA and SASPs [50].

Differently, the Raman spectra from the most resistant SBP3 spores showed small changes in the band that referred to proteins after heat treatment (Figure 5). What is even more interesting is the slight separation observed in the PCA between untreated and wet-heat-treated SBP3 spores, indicating the major spore stability of the thermophilic strain (Figure 5).

\section{Conclusions}

The FTIR spectra showed that spores of SBP3, BHO and BSU strains mainly differed in the regions that referred to lipids, consisting of more saturated fatty acids in SBP3, and to amino acids or polypeptides, indicating that the protein structures of SBP3 and BHO spores were more aggregated and complex than those of BSU.

The SBP3 spores exhibited a more robust resistance to wet heat treatment $\left(98^{\circ} \mathrm{C}\right)$, as shown by the highest $\mathrm{LD}_{90}$ value, than $\mathrm{BHO}$ and BSU did.

Minor changes were observed in the Raman spectrum of the heat-treated SBP3 spores that referred to lipids and proteins, indicating that SBP3 spore resistance is related to the intrinsic thermostability of lipids and protein structures.

These results suggest that the stability of SBP3 spore structures, mainly proteins, in wet heat allows them to resist the thermal stress naturally experienced and could be involved in the resistance to multiple stresses previously reported.

Our findings provide basic information for further comparative studies into spore responses to natural and laboratory stresses that are useful in different contexts, including astrobiology.

Author Contributions: Conceptualization, V.Z. and C.G.; methodology, V.Z. and M.T.C.; software, M.T.C.; validation, S.G., S.M. and V.Z.; formal analysis, M.T.C.; investigation, V.Z.; resources, A.S.; data curation, C.G.; writing—original draft preparation, V.Z.; writing—review and editing, C.G. and S.G.; visualization, M.T.C.; supervision, C.G. and S.M. All authors have read and agreed to the published version of the manuscript.

Funding: This research received no external funding.

Institutional Review Board Statement: Not applicable.

Informed Consent Statement: Not applicable.

Data Availability Statement: No data supporting.

Conflicts of Interest: The authors declare no conflict of interest.

\section{References}

1. Cortesão, M.; Fuchs, F.M.; Commichau, F.M.; Eichenberger, P.; Schuerger, A.C.; Nicholson, W.L.; Setlow, P.; Moeller, R. Ba-cillus subtilis Spore Resistance to Simulated Mars Surface Conditions. Front. Microbiol. 2019, 10, 333. [CrossRef]

2. Nicholson, W.L.; Munakata, N.; Horneck, G.; Melosh, H.J.; Setlow, P. Resistance of Bacillus Endospores to Extreme Terrestrial and Extraterrestrial Environments. Microbiol. Mol. Biol. Rev. 2000, 64, 548-572. [CrossRef] [PubMed]

3. Zammuto, V.; Fuchs, F.M.; Fiebrandt, M.; Stapelmann, K.; Ulrich, N.J.; Maugeri, T.L.; Pukall, R.; Gugliandolo, C.; Moeller, R. Comparing Spore Resistance ofBacillusStrains Isolated from Hydrothermal Vents and Spacecraft Assembly Facilities to Environmental Stressors and Decontamination Treatments. Astrobiology 2018, 18, 1425-1434. [CrossRef]

4. Setlow, P. Spores of Bacillus subtilis: Their resistance to and killing by radiation, heat and chemicals. J. Appl. Microbiol. 2006, 101, 514-525. [CrossRef] [PubMed] 
5. Moeller, R.; Schuerger, A.C.; Reitz, G.; Nicholson, W.L. Protective Role of Spore Structural Components in Determining Bacillus subtilis Spore Resistance to Simulated Mars Surface Conditions. Appl. Environ. Microbiol. 2012, 78, 8849-8853. [CrossRef] [PubMed]

6. Zammuto, V.; Rizzo, M.G.; De Plano, L.M.; Franco, D.; Guglielmino, S.; Caccamo, M.T.; Magazù, S.; Fujimori, A.; Lo Giudice, A.; Guglielmin, M.; et al. Effects of Heavy Ion Particle Irradiation on Spore Germina-tion of Bacillus spp. from Extremely Hot and Cold Environments. Life 2020, 10, 264. [CrossRef] [PubMed]

7. Maugeri, T.L.; Gugliandolo, C.; Caccamo, D.; Stackebrandt, E. Three novel halotolerant and thermophilic Geobacillus strains from shallow marine vents. Syst. Appl. Microbiol. 2002, 25, 450-455. [CrossRef]

8. Gugliandolo, C.; Lentini, V.; Spanò, A.; Maugeri, T. New bacilli from shallow hydrothermal vents of Panarea Island (Italy) and their biotechnological potential. J. Appl. Microbiol. 2012, 112, 1102-1112. [CrossRef]

9. Zammuto, V.; Gugliandolo, C. Resistance to high temperatures of spores from bacilli of shallow hydrothermal vent origins. AAPP Phys. Math. Nat. Sci. 2019, 97, 28. [CrossRef]

10. Vaishampayan, P.; Probst, A.; Krishnamurthi, S.; Ghosh, S.; Osman, S.; McDowall, A.; Ruckmani, A.; Mayilraj, S.; Venkateswaran, K. Bacillus horneckiae sp. nov., isolated from a spacecraft-assembly clean room. Int. J. Syst. Evol. Microbiol. 2010, 60, 1031-1037. [CrossRef]

11. Caccamo, M.T.; Gugliandolo, C.; Zammuto, V.; Magazù, S. Thermal properties of an exopolysaccharide produced by a ma-rine thermotolerant Bacillus licheniformis by ATR-FTIR spectroscopy. Int. J. Biol. Macromol. 2019, 145, 77-83. [CrossRef]

12. Maisano, G.; Majolino, D.; Migliardo, P.; Venuto, S.; Aliotta, F.; Magazú, S. Sound velocity and hydration phenomena in aqueous polymeric solutions. Mol. Phys. 1993, 78, 421-435. [CrossRef]

13. Caccamo, M.T.; Magazù, S. Tagging the oligomer-to-polymer crossover on EG and PEGs by infrared and Raman spectros-copies and by wavelet cross-correlation spectral analysis. Vib. Spectr. 2016, 85, 222-227. [CrossRef]

14. Cannuli, A.; Caccamo, M.T.; Castorina, G.; Colombo, F.; Magazù, S. Laser Techniques on Acoustically Levitated Droplets. EPJ Web Conf. 2018, 167, 5010. [CrossRef]

15. Caccamo, M.T.; Cannuli, A.; Magazù, S. Wavelet analysis of near-resonant series RLC circuit with time-dependent forcing frequency. Eur. J. Phys. 2018, 39, 045702. [CrossRef]

16. Nawaz, H.; Bonnier, F.; Knief, P.; Howe, O.; Lyng, F.M.; Meade, A.D.; Byrne, H.J. Evaluation of the potential of Raman microspectroscopy for prediction of chemotherapeutic response to cisplatin in lung adenocarcinoma. Analyst 2010, 135, 3070-3076 [CrossRef] [PubMed]

17. Managò, S.; Valente, C.; Mirabelli, P.; Circolo, D.; Basile, F.; Corda, D.; De Luca, A.C. A reliable Raman-spectroscopy-based approach for diagnosis, classification and follow-up of B-cell acute lymphoblastic leukemia. Sci. Rep. 2016, 6, 24821. [CrossRef]

18. Venables, W.N.; Ripley, B.D. Modern Applied Statistics with S, 4th ed.; Springer: New York, NY, USA, 2002; ISBN 0-387-95457-0. Available online: https:/ / www.stats.ox.ac.uk/pub/MASS4/ (accessed on 7 May 2021).

19. Vongsvivut, J.; Heraud, P.; Zhang, W.; Kralovec, J.A.; McNaughton, D.; Barrow, C.J. Rapid Determination of Protein Con-tents in Microencapsulated Fish Oil Supplements by ATR-FTIR Spectroscopy and Partial Least Square Regression (PLSR) Analysis. Food Bioprocess Tech. 2013, 7, 265-277. [CrossRef]

20. Guillén, M.D.; Cabo, N. Characterization of edible oils and lard by fourier transform infrared spectroscopy. Relationships between composition and frequency of concrete bands in the fingerprint region. J. Am. Oil Chem. Soc. 1997, 74, 1281-1286. [CrossRef]

21. Filip, Z.; Herrmann, S.; Kubát, J. FT-IR spectroscopic characteristics of dierently cultivated Bacillus subtilis. Microbiol. Res. 2004, 159, 257-262. [CrossRef]

22. Böcker, U.; Wubshet, S.G.; Lindberg, D.; Afseth, N.K. Fourier-transform infrared spectroscopy for characterization of protein chain reductions in enzymatic reactions. Analyst 2017, 142, 2812-2818. [CrossRef]

23. Serrano, V.; Liu, W.-G.; Franzen, S. An Infrared Spectroscopic Study of the Conformational Transition of Elastin-Like Poly-peptides. Biophys. J. 2007, 93, 2429-2435. [CrossRef]

24. Perkins, D.L.; Lovell, C.R.; Bronk, B.V.; Setlow, B.; Setlow, P.; Myrick, M.L. Fourier transform infrared reflectance mi-crospectroscopy study of Bacillus subtilis engineered without dipicolinic acid: The contribution of calcium dipicolinate to the mid-infrared absorbance of Bacillus subtilis endospores. Appl. Spectrosc. 2005, 59, 893-896. [CrossRef] [PubMed]

25. Bizani, D.; Motta, A.S.; Morrissy, J.A.C.; Terra, R.M.S.; Souto, A.A.; Brandelli, A. Antibacterial activity of cerein 8A, a bacte-riocinlike peptide produced by Bacillus cereus. Int. Microbiol. 2005, 8, 125-131.

26. Rohman, A.; Man, Y.C. Fourier transform infrared (FTIR) spectroscopy for analysis of extra virgin olive oil adulterated with palm oil. Food Res. Int. 2010, 43, 886-892. [CrossRef]

27. Zelig, U.; Mordechai, S.; Shubinsky, G.; Sahu, R.K.; Huleihel, M.; Leibovitz, E.; Nathan, I.; Kapelushnik, J. Pre-screening and followup of childhood acute leukemia using biochemical infrared analysis of peripheral blood mononuclear cells. Biochim. Biophys. Acta 2011, 1810, 827-835. [CrossRef] [PubMed]

28. De Gelder, J.; Scheldeman, P.; Leus, K.; Heyndrickx, M.; Vandenabeele, P.; Moens, L.; De Vos, P. Raman spectroscopic study of bacterial endospores. Anal. Bioanal. Chem. 2007, 389, 2143-2151. [CrossRef] [PubMed]

29. Çulha, M.; Adigüzel, A.; Yazici, M.M.; Kahraman, M.; Slahin, F.; Güllüce, M. Characterization of Thermophilic Bacteria Using Surface-Enhanced Raman Scattering. Appl. Spectrosc. 2008, 62, 1226-1232. [CrossRef]

30. Kong, L.; Setlow, P.; Li, Y.-Q. Analysis of the Raman spectra of $\mathrm{Ca}^{2+}$-dipicolinic acid alone and in the bacterial spore core in both aqueous and dehydrated environments. Analyst 2012, 137, 3683-3689. [CrossRef] 
31. Nelson, W.H.; Dasari, R.; Feld, M.; Sperry, J.F. Intensities of Calcium Dipicolinate andBacillus SubtilisSpore Raman Spectra Excited with $244 \mathrm{~nm}$ Light. Appl. Spectrosc. 2004, 58, 1408-1412. [CrossRef]

32. Zhang, P.; Kong, L.; Setlow, P.; Li, Y.Q. Characterization of wetheat inactivation of single spores of Bacillus species by du-al-trap Raman spectroscopy and elastic light scattering. Appl. Environ. Microbiol. 2010, 76, 1796-1805. [CrossRef]

33. Wolkers, W.F.; Oliver, A.E.; Tablin, F.; Crowe, J.H. A Fourier-transform infrared spectroscopy study of sugar glasses. Carbohydr. Res. 2004, 339, 1077-1085. [CrossRef]

34. Noothalapati, H.; Sasaki, T.; Kaino, T.; Kawamukai, M.; Ando, M.; Hamaguchi, H.O.; Yamamoto, T. Label-free chemical im-aging of fungal spore walls by Raman microscopy and multivariate curve resolution. Anal. Sci. Rep. 2016, 6, 27789. [CrossRef]

35. Rusciano, G.; Capriglione, P.; Pesce, G.; Abete, P.; Carnovale, V.; Sasso, A. Raman spectroscopy as a new tool for early de-tection of bacteria in patients with cystic fibrosis. Laser Phys. Lett. 2013, 10, 075603. [CrossRef]

36. Atrih, A.; Foster, S.J. Bacterial endospores the ultimate survivors. Int. Dairy J. 2002, 12, 217-223. [CrossRef]

37. Driks, A. Bacillus subtilis Spore Coat. Microbiol. Mol. Biol. Rev. 1999, 63, 1-20. [CrossRef] [PubMed]

38. Russell, A.D. Bacterial spores and chemical sporicidal agents. Clin. Microbiol. Rev. 1990, 3, 99-119. [CrossRef]

39. Cho, W.-I.; Chung, M.-S. Bacillus spores: A review of their properties and inactivation processing technologies. Food Sci. Biotechnol. 2020, 29, 1447-1461. [CrossRef] [PubMed]

40. Coleman, W.; Setlow, P. Analysis of damage due to moist heat treatment of spores of Bacillus subtilis. J. Appl. Microbiol. 2009, 106, 1600-1607. [CrossRef]

41. Belliveau, J.W.; Kwong, K.K.; Kennedy, D.N.; Baker, J.R.; Stern, C.E.; Benson, R.; Chesler, D.A.; Weisskoff, R.M.; Cohen, M.S.; Tootell, R.B.H.; et al. Magnetic resonance imaging mapping of brain function human visual cor-tex. Investig. Radiol. 1992, 27, S59. [CrossRef]

42. Setlow, P. Spore resistance properties. In The Bacterial Spore: From Molecules to Systems; American Society of Microbiology: Washington, DC, USA, 2016; pp. 201-215.

43. Mysliwiec, T.H.; Tierno, A.F.; Aurentz, D.J. Characterization of Bacillus subtilis sporulation and bacteriophage infection via FT-IR spectroscopy. J. Spect. 2009, 23, 456049. [CrossRef]

44. Subramanian, A.; Ahn, J.; Balasubramaniam, V.M.; Rodriguez-Saona, L. Monitoring Biochemical Changes in Bacterial Spore during Thermal and Pressure-Assisted Thermal Processing using FT-IR Spectroscopy. J. Agric. Food Chem. 2007, 55, 9311-9317. [CrossRef]

45. Guicheteau, J.; Argue, L.; Emge, D.; Hyre, A.; Jacobson, M.; Christesen, S. Bacillus Spore Classification via Surface-Enhanced Raman Spectroscopy and Principal Component Analysis. Appl. Spectrosc. 2008, 62, 267-272. [CrossRef] [PubMed]

46. Chou, K.-C.; Cai, Y.-D. Predicting protein structural class by functional domain composition. Biochem. Biophys. Res. Commun. 2004, 321, 1007-1009. [CrossRef] [PubMed]

47. Koga, Y. Thermal Adaptation of the Archaeal and Bacterial Lipid Membranes. Archaea 2012, 2012, 1-6. [CrossRef]

48. Roberts, M.S.; Nakamura, L.K.; Cohan, F.M. Bacillus mojavensis sp. nov., distinguishable from Bacillus subtilis by sexual iso-lation, divergence in DNA sequence, and differences in fatty acid composition. Int. J. Syst. Evol. Microbiol. 1994, 44, 256-264.

49. Coleman, W.H.; Chen, D.; Li, Y.-Q.; Cowan, A.E.; Setlow, P. How Moist Heat Kills Spores of Bacillus subtilis. J. Bacteriol. 2007, 189, 8458-8466. [CrossRef]

50. Besten, H.M.D.; Wells-Bennik, M.H.; Zwietering, M.H. Natural Diversity in Heat Resistance of Bacteria and Bacterial Spores: Impact on Food Safety and Quality. Annu. Rev. Food Sci. Technol. 2018, 9, 383-410. [CrossRef] 